Article

\title{
Understanding the Perceptions of Sustainable Coffee Production: A Case Study of the K'Ho Ethnic Minority in a Small Village in Lâm Đồng Province of Vietnam
}

\author{
Quan Vu Le ${ }^{1, *}$, Grace Jovanovic ${ }^{2}$, Don-Thuan Le $^{3}$ and Sanya Cowal ${ }^{2}$ \\ 1 College of Business and Management, Vin University, 458 Minh Khai Street, Tower 1, Hai Ba Trung District, \\ Hanoi 100000, Vietnam \\ 2 College of Arts and Sciences, Seattle University, Seattle, WA 98112, USA; gracejovanovic@gmail.com (G.J.); \\ cowals@seattleu.edu (S.C.) \\ 3 College of Science and Engineering, Seattle University, Seattle, WA 98112, USA; led7@seattleu.edu \\ * Correspondence: v.quanlv2@vingroup.net or quaanlv@gmail.com
}

Received: 13 December 2019; Accepted: 23 January 2020; Published: 31 January 2020

check for updates

\begin{abstract}
This case study used anthropological and culture concept methodologies to evaluate the perceptions of sustainable coffee production of the K'Ho ethnic minority in Di Linh district, Lâm Đồng province in the Central Highlands of Vietnam. Sustainable production is a means of mitigating the increasing impacts of climate change upon the region. The Central Highlands is a major coffee production hub and Di Linh is the largest coffee growing region of Lâm Đồng province. The case study included in-depth interviews with farmers based on open-ended questions and a questionnaire about sustainable coffee indicators. The survey invited farmers to quantify the current status of their social, economic, and environmental sustainability. Our study revealed that the unique, government sponsored development of coffee farms led to fast production rates and quick economic prosperity. But, it also resulted in a prolonged monoculture system of coffee production and high chemical use; causing farm productivity to decline and social, economic, and environmental vulnerability to increase. The K'Ho farmers in a small village are noticing the devastating long-term effects of agrochemicals, but have had some initial success exploring the potential benefits of reverting to traditional farming methods.
\end{abstract}

Keywords: sustainable coffee; climate change; ethnic minorities; farmers; central highlands; Vietnam

\section{Introduction}

Coffee is the second most traded commodity in the world after crude oil, and Vietnam is the world's second-largest producer of coffee. Coffee trees were first introduced to Vietnam by the French in 1857. They were planted and maintained by the ethnic minorities in the Central Highlands for generations. Because of the favorable climate and fertile soils, these regions are known as the production hub for coffee in Vietnam. Severe impacts of climate change in recent years, particularly rising temperatures and irregular rain patterns, have caused these regions to become less suitable for growing coffee. Conditions are projected to worsen in the foreseeable future [1].

The objective of this case study is to examine sustainable coffee farming as a means of mitigating the increasing impacts of climate change on coffee production. Sustainable coffee allows future generations of farmers to continue producing coffee. Sustainability means environmental, social, and economic sustainability [2]. The research site for this paper is in Lăng Cú village, in the Gung Ré commune of Di Linh district, Lâm Đồng province of the Central Highlands of Vietnam. The K'Ho ethnic minority are the largest group among the ethnic minorities in the district. The $\mathrm{K}^{\prime} \mathrm{Ho}$ farmers in 
the province have been growing coffee for many generations since the French introduced the coffee trees in this region. Initially, they produced coffee using traditional farming practices without chemicals. However, the government began subsidizing crops and chemical fertilizers to help farmers develop the agricultural sector in the early 1990s. Coffee was established as a means of poverty reduction. Farmers in the region, including the $\mathrm{K}^{\prime} \mathrm{Ho}$ community, switched to using large quantities of chemical fertilizers and pesticides for the past thirty years resulting in high productivity. Within a few years, the coffee industry exploded. However, after three decades of high yields, the region has begun facing many issues such as a dependency on chemicals, increased erosion, and decreased productivity.

In recent years, the $\mathrm{K}^{\prime} \mathrm{Ho}$ farmers want to revert back to organic farming, recognizing the negative impacts of chemicals. Particularly, the K'Ho Nộp farmers in Lăng Cú village are noticing the devastating long-term effects of agrochemicals, but have had some initial success exploring the potential benefits of traditional farming methods. Agrochemicals produce short-term results including greater coffee yields; but have many long-term negative effects [3]. The most obvious one is the introduction of artificial and unrecognized components into the soil and ecosystem. The application of inorganic fertilizers $(\mathrm{NPK})$-nitrogen $(\mathrm{N})$, phosphorus $(\mathrm{P})$, and potassium $(\mathrm{K})$ often inhibits the soil's natural ability to replenish its nutrients, leading to infertile land. Over time, chemical use across the farm makes each individual coffee tree weaker and less stable. This also increases susceptibility to disease compared to organic coffee trees that have not been chemically treated. The negative consequences of fertilizers will probably be worsened by climate change since it is projected to induce higher temperatures and precipitation levels, further impacting coffee tree growth.

Coffee, like many crops, thrives in a relatively small window of ideal conditions. Coffea canphora or Robusta coffee, the coffee varietal grown in lower elevation regions like that of Di Linh district, requires temperature ranges of $20-30^{\circ} \mathrm{C}$ and appropriate timing of rains to support the development of flowers, but little to no rain during blooms to avoid damaging the coffee cherries [4]. Scientists from the World Coffee Research Organization [5] have determined a range of climatic conditions that would qualify an area as no longer suitable for coffee production and found the main causal factor to be the average temperature during the hottest month. Currently, $25 \%$ of coffee growing areas reach temperatures higher than $30{ }^{\circ} \mathrm{C}$ during the hottest months; and, that is projected to increase to $79 \%$ by 2050 . Additionally, $54 \%$ of areas are projected to reach even hotter maximum temperatures up to $32{ }^{\circ} \mathrm{C}$ by 2050 [5]. Therefore, a majority of coffee farms are projected to experience higher averages of maximum temperature levels, which will have major implications for the health of coffee trees in the future.

Accordingly, many farmers and global organizations have been working to promote sustainable coffee production to increase the resilience of farms to changing conditions. This includes increasing the biodiversity of farms through intercropping, decreasing reliance on pesticides and fertilizers, increasing shade trees on farms, and introducing natural fungicides and insecticides to combat common pests. Intercropping, or the planting of several varieties of crops in a given area, improves land efficiency through the increased nutrient distribution and uptake, effective use of water resources, and increased soil stability [6]. Decreasing reliance on pesticides and fertilizers allows the soil to balance its nutrients naturally and prevents the introduction of foreign chemicals into a given area, while simultaneously decreasing farmers' input costs for production. Introducing shade trees to coffee farms decreases direct sunlight that can sometimes damage coffee trees; shade trees also decrease the wind distribution of pests such as coffee leaf rust. But, shade trees have also been shown to increase the prevalence of the coffee leaf rust since they provide humid environments with low light and moderate temperatures; promoting spore germination of the rust [7]. Therefore, careful consideration of the condition of each farm is essential for establishing effective sustainable measures. Lastly, introducing natural fungicides and insecticides to combat pests, such as the white halo fungus, increases the natural biodiversity of farms and promotes healthy relationships and balances of species on the farm. Research has shown that several fungal species are hyper-parasites on coffee rust, including Lecanicillium lecanii and at least 10 other fungal species [8]. 
The paper is set out as follows: Section 2 provides background on Lâm Đồng province and the history of $\mathrm{K}^{\prime} \mathrm{Ho}$ ethnic minorities living in this region. Section 3 describes the research methodology and survey instruments. Section 4 provides the findings of the perceptions of sustainable coffee production of the $\mathrm{K}^{\prime} \mathrm{Ho}$ coffee farmers. Section 5 is the conclusion.

\section{Background}

\subsection{Geography and Agriculture in Lâm Đồng Province}

Lâm Đồng province is one of the five provinces in the Central Highlands of Vietnam, located on three plateaus with an altitude between $800-1500 \mathrm{~m}$ above sea level. It is the seventh largest province in the country, covering $9722 \mathrm{~km}^{2}$. The province borders Đồng Nai province to the southwest, Bình Thuận province to the southeast, Khánh Hòa province to the east, and Đắk Lắk province to the north. Lâm Đồng province has a population of 1.29 million residents (2017) and is home to the majority Kinh (Việt) and ethnic minorities including the $\mathrm{K}^{\prime} \mathrm{Ho}$, Churu, Mạ, and M'Nông. The K'Ho is the largest among the ethnic minority groups.

Agriculture is one of the key economic sectors of Lâm Đồng province with three main cash crops: 150,770 hectares of coffee (89\% Robusta and 11\% Arabica); 23,880 hectares of cashew; and 18,240 hectares of tea [9]. The Central Highlands produce $90 \%$ of the total coffee output in Vietnam. Coffee production in Lâm Đồng province ranks second after Đắk Lắk province, but is the largest Arabica coffee producer with 17,120 hectares. The coffee industry in Lâm Đồng province is taking steps towards sustainable coffee production by investing in certifications of their farms through international standards. The results in recent years show that sustainable coffee production has increased productivity and quality of coffee and brought economic benefits to the farmers. In particular, the average yield is about 3.5-4.0 tons of green beans per hectare per year. This is higher than unsustainable coffee production which has average yields of about 2.6-3.2 tons of green beans per hectare per year [9].

\subsection{The K'Ho Ethnic Minority in Lâm Đồng Province}

According to the 2009 Census, there are about 166,112 K'Ho residing in 46 out of 63 provinces and cities in Vietnam. They mainly live in Lâm Đồng, Bình Thuận, Khánh Hòa, and Ninh Thuận provinces. The $\mathrm{K}^{\prime} \mathrm{Ho}$ population in Lâm Đồng province is approximately 145,665 people, which accounts for $87.7 \%$ of the K'Ho ethnic minority in Vietnam [10]. The K'Ho communities in the province are not concentrated in one area. Instead, they are divided into multiple subgroups based on location, language, and culture. The K'Ho Srê is the largest group followed by the K'Ho Chil. The K'Ho Srê reside mainly in the Di Linh plateau, while the K'Ho Chil are concentrated around Lang Biang mountain in Lạc Dương. The $\mathrm{K}^{\prime} \mathrm{Ho}$ Chil had a nomadic lifestyle moving down from the mountainous areas to the lower lands over the years. The K'Ho Lat live in Lat commune and in the valleys of Đà Lạt. Because of regular interactions with the Kinh (Việt) for many generations, the K'Ho Lạt have made significant socio-economic integration compared to the other $\mathrm{K}^{\prime} \mathrm{Ho}$ subgroups. The K'Ho Nộp and $\mathrm{K}^{\prime} \mathrm{Ho}$ Cờ Đôn ( $\left.\mathrm{K}^{\prime} \mathrm{Yo}\right)$ reside in Di Linh district, and the $\mathrm{K}^{\prime} \mathrm{Ho} \mathrm{T}^{\prime}$ ring live to the east of Lâm Đồng province and in Khánh Hòa province.

The K'Ho have a unique culture with their own customary laws affecting family and community [10]. The administrative structure of the $\mathrm{K}^{\prime} H o$ is called bòn: a self-governing unit responsible for socio-economic development of the community. Bòn is a traditional commune-style village organized in line with matriarchy. In the $\mathrm{K}^{\prime} \mathrm{Ho}$ community, women are the pillar of the family. They are entitled to decision-making for all important events including engagements, weddings, funerals, and other activities. Children bear the K'Ho mother's surname and daughters are the inheritors; with the youngest daughter typically being the sole inheritor. The chief of the bòn is the village patriarch: kwang bòn. The patriarch is similar in terms of economic status to other villagers, but spiritually, he has almost absolute prestige. The rights and obligations of each kwang bòn are broad and 
comprehensive, including: politically, being the highest representative of the village as an independent social organization unit with equal rights as other kwang bòn in surrounding villages; economically, through managing the daily business of the village such as production and management of natural resources; and socially, through coordinating relationships among members in the community [10].

Religion is an integral part of the K'Ho's communal life [11]. They are polytheistic and their supreme God is Nđu (Yàng), who enlightens the universe and has the ultimate power to protect people. Similar to other ethnic minority groups living in the Central Highlands, the K'Ho have preserved many unique traditional cultural values. They practice rituals in honor of the Gods during important occasions such as weddings, funerals, crop prayers, and other ceremonies. Catholicism was introduced to the K'Ho in the Lâm Đồng plateaus more than 90 years ago by missionaries [11]. The first $\mathrm{K}^{\prime} \mathrm{Ho}$ was baptized in 1927 in Di Linh district. In 1929, Protestantism was introduced to the K'Ho ethnic minority communities in Lâm Đồng province [11]. Protestantism was later expanded in the 1960s during the Vietnam War when the $\mathrm{K}^{\prime} \mathrm{Ho}$ minorities were forced to leave their traditional villages in the mountainous areas to resettle into villages along with the Kinh (Việt) and other ethnic minorities in the lowlands. Today, the K'Ho communities mainly practice Catholicism or Protestantism.

The emergence of Catholicism and Protestantism in the $\mathrm{K}^{\prime} \mathrm{Ho}$ communities has led to many social and cultural changes [11]. Today, the K'Ho communities still respect their traditional customary laws, which are valuable spiritual assets; but some laws have gradually disappeared in their communities. This could be seen as a positive sign since several customary laws cause major financial burdens to many families [10]. For example, for the wedding ceremony, the family of the bride has to bring to the groom's family the following items: buffaloes, pigs, chickens, rice, traditional ché wine, blankets, bronze and aluminum necklaces, etc. This is a great financial burden for families, especially as prices of products at modern markets rise.

There are typically two types of family structures in the $\mathrm{K}^{\prime} \mathrm{Ho}$ community-large families and small families. A large family consists of 10-30 members spanning 3-4 generations, and often includes many small family groups. Large families share the same land, animals, and other properties. The head of the large family is the patriarch, who is often the husband of the oldest woman in the family. The process of disintegration of large families and the transition from large families to small families is occurring rapidly today. Small families are becoming increasingly common owing to the internal development of the $\mathrm{K}^{\prime} \mathrm{Ho}$ community and the influence of external social factors. A typical small family consists of 2 to 9 members. Marriage age is usually 16-17 years for females and 18-20 years for males. To this day, a young $\mathrm{K}^{\prime} \mathrm{Ho}$ woman chooses her man, marries him, and brings him back to her home. On average, a woman gives birth to $5-6$ children.

\subsection{Historical Farming Practices of the $\mathrm{K}^{\prime} \mathrm{Ho}$}

Agriculture was historically, and continues to be, an important form of the K'Ho lifestyle. The $\mathrm{K}^{\prime} \mathrm{Ho}$ subgroups have different farming practices depending on the soil conditions and climates in their areas. For example, the K'Ho Srê cultivates lowland (wet) rice. Other K'Ho subgroups practice shifting cultivation and nomadic farming of crops such as upland (dry) rice, maize, and cassava. The traditional practice of the $\mathrm{K}^{\prime} \mathrm{Ho}$ Chil is to cultivate upland fields in a closed cycle, planting for two years, leaving unplanted for 10 or 15 years, and then replanting. Today, however, owing to the degradation of upland fields, deforestation, and soil erosion, the K'Ho Chil have shifted their practices to fixed cultivation [10]. Fixed cultivation is when an old field is selected, and all the remaining roots and trees are dug up and burned to clear the land. The newly burned material leaves behind a rich carbon layer which facilitates the quick and healthy growth of new crops planted in the field.

Animal husbandry is also important in the K'Ho community. They raise water buffalos, cows, pigs, goats, and other animals on their land. Historically, the purpose of raising these animals was mainly to fulfill spiritual needs such as offerings, funerals, and weddings rather than to improve the nutritional value of the $\mathrm{K}^{\prime} \mathrm{Ho}$ diet, so animals have not become a major commodity product [10]. 
That has begun to shift, however, with modernization and access to local markets, where the K'Ho frequently goes to purchase meats for specific meals and festivals.

\subsection{Di Linh District and the K'Ho Communities}

Di Linh district has a total area of $1628 \mathrm{~km}^{2}$. Di Linh district is characterized as having a tropical monsoon climate with high altitude and mild temperatures throughout the year, which is suitable for cultivating tropical plants and animals. The district's predominant types of terrain are plateau terrain, suitable for planting fruit trees and wet rice; and mountain terrain, located in the south and southwest of the district with natural forests and environmental protection areas. The forested area covers 83,139 hectares, accounting for $51 \%$ of the total natural area.

Di Linh district has historically been one of the more impoverished districts in the province. The economic condition gradually began to improve about 10 years ago when the local government introduced initiatives to increase productivity in coffee, tea, and tropical fruit trees. In 2008, coffee trees planted in the district were about 30,000 hectares, mainly old varieties with low productivity that would yield about 2 tons of green beans/hectare. Today, Di Linh district has 41,000 hectares of coffee, accounting for $75 \%$ of agricultural land. More than $50 \%$ of coffee plants have been replanted with new varieties. Di Linh district has become the largest coffee producing area in Lâm Đồng province, averaging 100,000 tons of green beans/year at a value of 3400 billion VND (equivalent to $\$ 148$ million), which accounts for $85 \%$ of the total value of agricultural production in the district [12].

Farmers in Di Linh produce Robusta varieties. The introduction of sustainable farming to coffee producing areas has helped farmers gradually change their cultivation method and intensification practices in coffee production. Along with the focus on planting new coffee species and replanting low yield coffee trees, local authorities have emphasized their support for coffee purchasing and processing enterprises in the region [12]. Tea is the second largest commodity in Di Linh with 700 hectares of new plants, producing an estimated 9 tons/hectare. In addition, nearly 2500 tropical fruit trees such as macadamias, avocados, durians, and bananas have been planted to provide shade for coffee. In order to ensure food security for the ethnic minorities, Di Linh district provides training for farmers in modern farming techniques and new varieties to increase productivity of wet rice. Between the years 2008-2017, the government provided 47 billion VND to support farmers' purchases of fertilizers, plants and animal breeds, and agricultural equipment. Rice yield in the district has increased from about 1.2 tons/hectare per harvest in 2008 to 5 tons/hectare per harvest in 2018. Net income has increased from 83 million VND/hectare to 132 million VND/hectare in the same period.

Di Linh district has a total population of 166,466 (2009), 37\% of whom are ethnic minorities $(61,659$ people). The urban population is about $12 \%$ and the rural population is about $88 \%$. During the period before 2000, Di Linh district's population increased rapidly with the average annual growth rate reaching $6.48 \%$. The rapid increase in coffee prices during this time was an incentive to people to migrate from the northern, central, and southern provinces to resettle and produce coffee. The population increased the fastest in the period 1995-2000, with an average annual increase of 7000-8000 people. In the period 2001-2005, the population gradually stabilized, at a population growth rate of about $2.6 \%$. The current population density is 95 people $/ \mathrm{km}^{2}$, much lower than the average density of the province: 1117 people $/ \mathrm{km}^{2}$. The K'Ho is the largest ethnic minority group in Di Linh district. The K'Ho Srê resides in Gung Ré, Bảo Thuận, Đinh Lạc, and Tân Nghĩa communes; the K'Ho Cờ Đôn ( $\mathrm{K}^{\prime} \mathrm{Y}$ ) lives mainly in Tân Thuợng and Đinh Trang Hòa communes; and the K'Ho Nộp is mainly in Gia Bắc and Sơn Điền communes. This study focuses on a small group of Catholic $\mathrm{K}^{\prime}$ Ho Nộp who migrated as a village 35 years ago from the upland Sơn Điền commune to the lowland Gung Ré commune located in the Di Linh plateau. After relocating, they integrated with the Protestant $\mathrm{K}^{\prime} \mathrm{Ho}$ Srê and the Kinh (Việt). 


\section{Methodology}

\subsection{Study Area}

We conducted fieldwork in 2019. The site of the survey is Lăng Cú village, Gung Ré commune, Di Linh district in Lâm Đồng province. Figure 1 provides a map of Di Linh district and Gung Ré commune. Table 1 provides the climatic indicators of the district. Di Linh district is at a similar altitude to other districts in the province at less than $1000 \mathrm{~m}$. It is at a lower elevation compared to Đà Lạt (1500 m) and Lac Dương district (1500-2200 m). The geographic and climatic conditions of this region are favorable for coffee, tea, and tropical fruit trees.

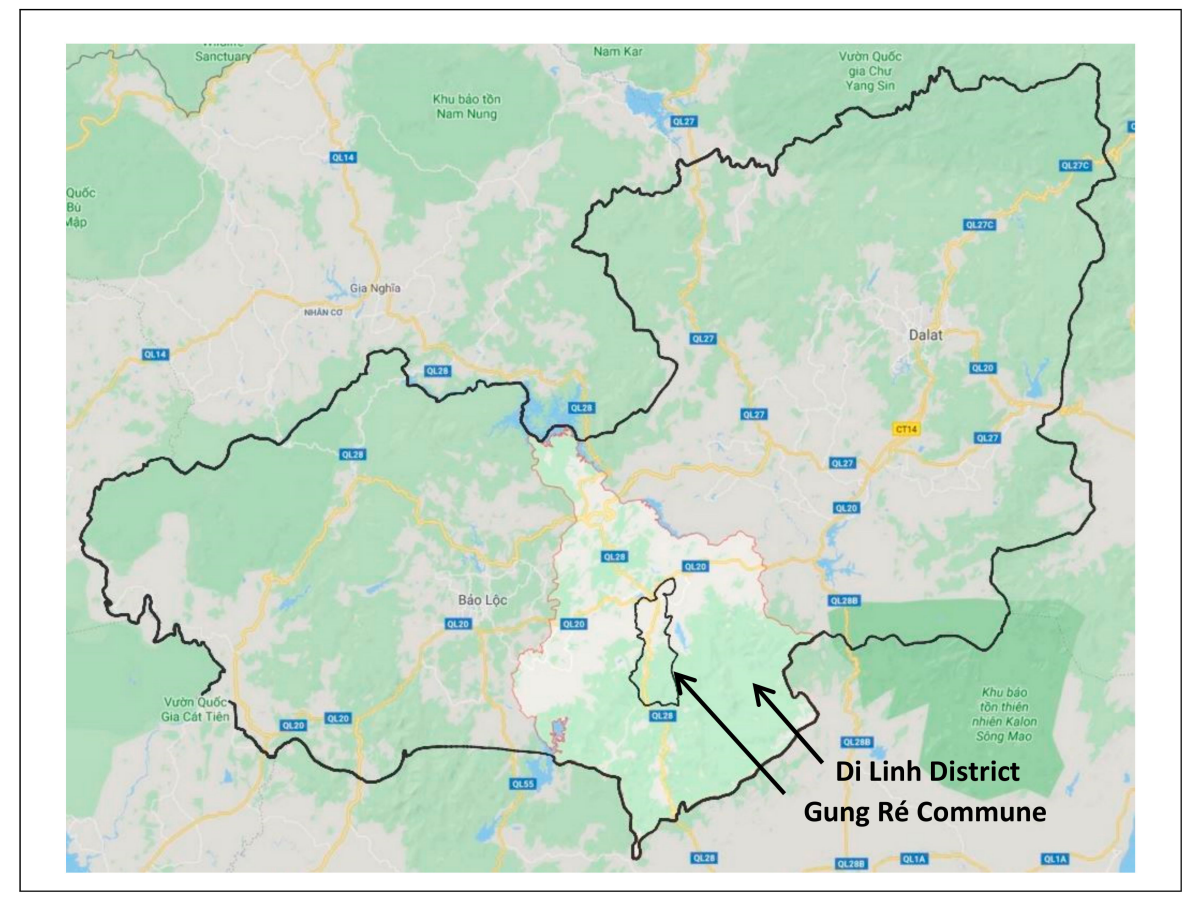

Figure 1. Map of Gung Ré commune and Di Linh district in Lâm Đồng. Source: Google Earth, Image @2019 DigitalGlobe.

Table 1. Climatic indicators of Di Linh district.

\begin{tabular}{cc}
\hline Indicator & Unit \\
\hline Altitude above sea level & $800-1000 \mathrm{~m}$ \\
Average temperature & $22.20^{\circ} \mathrm{C}$ \\
Temperature in the evening & $27.50{ }^{\circ} \mathrm{C}$ \\
Highest record average temperature & $17.00^{\circ} \mathrm{C}$ \\
Lowest record average temperature & $22.90^{\circ} \mathrm{C}$ \\
Month has the highest temperature (May) & $19.30^{\circ} \mathrm{C}$ \\
Month has the lowest temperature (January) & $764 \mathrm{~mm}$ \\
Average annual precipitation & $113 \mathrm{~mm}$ \\
Month with the highest precipitation (March) & $53.77 \mathrm{~mm}$ \\
Month with the lowest precipitation (September) & $150 \mathrm{days}$ \\
Days per year with precipitation and rainfall & $3103 \mathrm{~mm}$ \\
Annual rainfall & $897 \mathrm{~mm}$ \\
Month with the highest rainfall (August) & $4 \mathrm{~mm}$ \\
Month with the lowest rainfall (January) & $87 \%$ \\
Average humidity &
\end{tabular}

Source: Di Linh district, Lam Dong Portal.

Vietnam is one of the most disaster-prone nations in the world as a consequence of climate change. Between 1989 and 2008, natural disasters in Vietnam such as tropical storms, floods, drought, and 
landslides cost the country an average $1 \%$ of GDP per year [13]. The USDA (United States Department of Agriculture)'s May 2018 Global Agricultural Information Network (GAIN) Coffee Annual Report for Vietnam highlighted that coffee production in 2017 was at 29.3 million bags, approximately 600,000 bags lower than estimated (a 2\% decrease in total coffee produced for the 2017-2018 harvest season) because of late rains [14]. The report also noted that heavy rains in October and November of 2017 caused the initial harvest, about $10 \%$ of the total coffee grown, to be of poor quality. The early rains caused small beans to ripen prematurely, and disrupted the natural drying and storing of the processed beans.

Gung Ré commune has an area of $121.5 \mathrm{~km}^{2}$ with a population of under 9000 people (1999) and a population density of 69 people $/ \mathrm{km}^{2}$ [15]. Along with the Kinh (Việt), the K'Ho Srê and Nộp are the two ethnic minorities living in the commune. From 2010 to 2015, with the financial support from the government, Gung Ré commune introduced two major agricultural production programs to the local farmers [15]. The first is replanting 254.4 hectares of old coffee trees with new varieties, thus increasing yields from 1.5 tons of green beans/hectare to 2.5 tons/hectare. The second is introducing new rice varieties and irrigation systems for higher efficiency.

The exact location of this study is Lăng Cú village, where the majority of the K'Ho Nộp lives together as a migrant ethnic minority community. Figure 2 shows a map of Gung Ré commune and Lăng Cú village. Currently, the village has 185 households with 764 people, of which the K'Ho Nộp accounts for $40.5 \%$ [16]. The past few years, the local government has actively encouraged the ethnic minority community to participate in training programs in order to increase agricultural productivity, such as introducing new crop varieties and animal husbandry practices suitable to the local environment. To date, about 80 out of 330.7 hectares of coffee (approximately $25 \%$ of the area) have been replanted [16]. In addition, cows, goats, and pigs are raised for manure fertilizer and to supplement income from coffee and rice production.

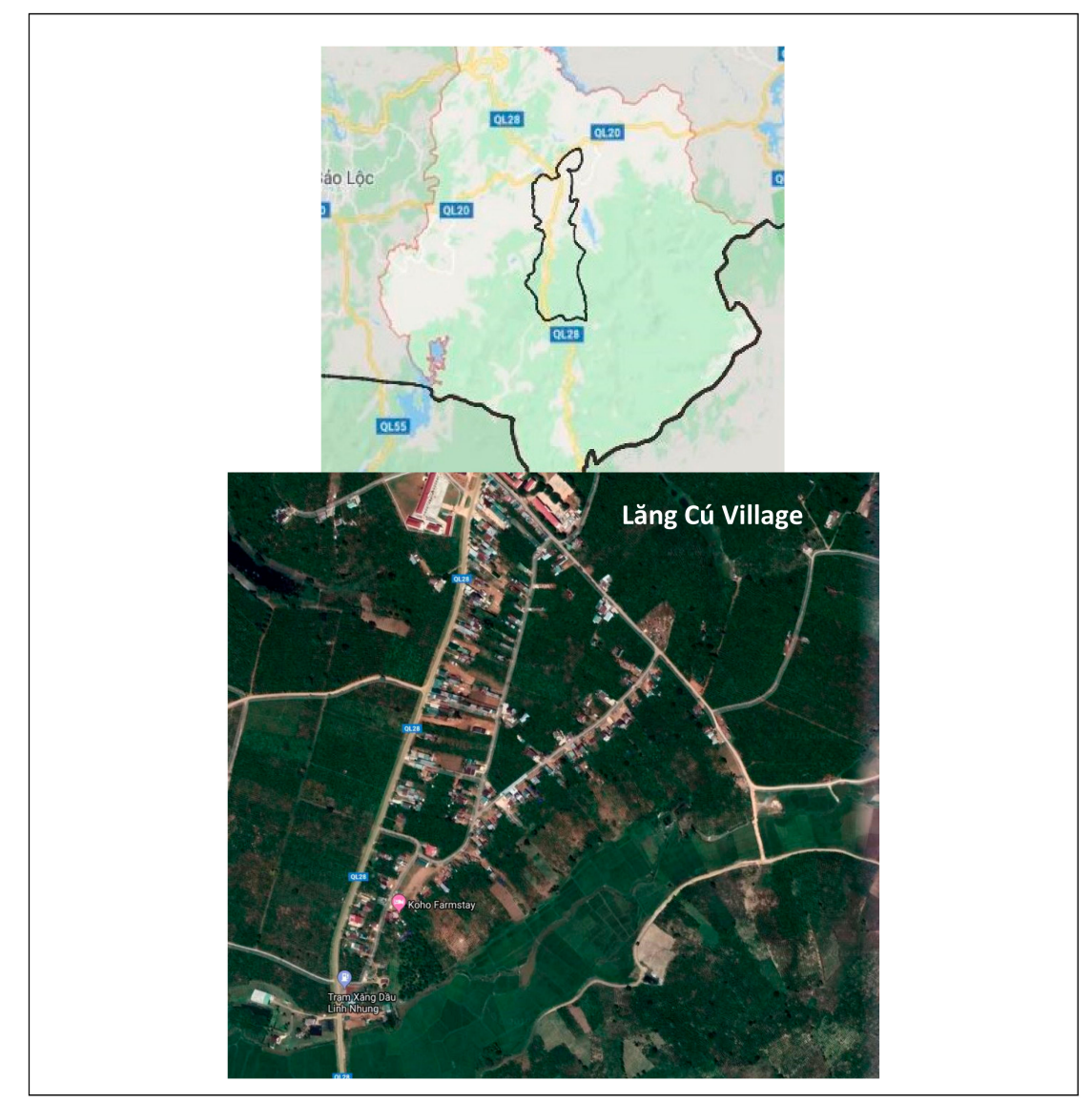

Figure 2. Map of Gung Ré commune and Lăng Cú village. Source: Google Earth, Image @2019 Digital Globe. 


\subsection{The Survey}

Survey methods were deemed by the investigators of this case study as being the most efficient and effective way of collecting data from disparate regions in Vietnam. Indeed, survey instruments have been administered to ethnic minorities in the country with good success in previous studies. We also utilized survey methods to study coffee farmers in Nicaragua with good results $[17,18]$. The K'Ho Nộp who participated in this study migrated to Lăng Cú village more than 35 years ago from Sơn Điền commune in the mountainous region bordered between Lâm Đồng province and Bình Thuận province. Fifteen families in the village were first moved to a resettlement area located in Di Linh town center. The local government initially gave the families land to split evenly, about $4000 \mathrm{~m}^{2}$ (four sào, each sào is equivalent to $1000 \mathrm{~m}^{2}$ ) and 100 coffee trees per family. Along the hillsides of Lăng Cú village, farmers began coffee production, while the flatlands were used for wet rice cultivation. Over the years, farmers independently expanded their crop lands; but about 15 years ago, the local government began restricting any form of land expansion. Today, each extended family has about 2-3 hectares of coffee farm and 1 hectare of wet rice field. The government also provided farmers with pesticides for rice cultivation, but ended this practice 6-7 years ago.

In order to understand the K'Ho farmers' perceptions of sustainable coffee production, we adapted the indicators of sustainable coffee from Coffee barometer 2014 [2] and modified them in our questionnaire. The sustainable coffee questionnaire consists of three parts. For each indicator, we asked the participants to compare the current condition with five years ago using a Likert scale: (1) Much worse; (2) Worse; (3) Same; (4) Better; (5) Much better. There are 5 indicators for social sustainability: food insecurity and malnutrition, access to education and healthcare, gender inequality, ageing farmer communities, and migration and young people leaving coffee farming. There are 6 indicators for economic sustainability: green bean price volatility, long term decreasing real coffee prices, lack of market and product information, rising living costs and living income, ageing coffee trees, and land tenure uncertainty. There are 7 indicators for environmental sustainability: deforestation, loss of biodiversity, soil erosion and degradation, use of agrochemicals, degradation of water quality and supply, evolving coffee pests and diseases, and climate change and volatility. These indicators were used to evaluate the overall perceptions of social, economic, and environmental sustainability of coffee production. The survey instrument was written in English, then translated into Vietnamese, and subsequently back-translated into English to assure consistency with the original questionnaire. In addition, we also conducted in-depth interviews with the farmers based on open-ended questions to assess their current farming practices and their understanding of sustainable coffee production. Many K'Ho farmers have knowledgeable verbal commands of Vietnamese language to provide us with answers when we asked them questions. For those who do not speak Vietnamese, we relied on a young $\mathrm{K}^{\prime} \mathrm{Ho}$ farmer to translate for the research team.

Thirty K'Ho coffee farmers participated in this survey; 13 were male and 17 were female. Twenty-two of the participants migrated to the village 35 years ago, and 8 were the second generation of the original fifteen families. The average age of the farmers is 52 years old. The youngest farmer is in the late twenties and the oldest farmer is over 80 years old. The average size of a family is 8 . Adult members in each household are responsible for the coffee farm, except during harvest season when they hire additional laborers to pick and process the cherries. All farmers grow Robusta coffee, which is suitable in this region. Only three out of 30 farmers grow both conventional and organic coffee. They are all young farmers with college educations and would like to resume traditional $\mathrm{K}^{\prime} \mathrm{Ho}$ farming practices after perceiving the negative impacts of chemicals. Organic coffee currently accounts for only $10 \%-20 \%$ of coffee produced since it is an experimental method of farming, based on shade-grown and regenerative farming practices. Many young farmers in the village are waiting to see the results of the few pioneers before they make an attempt to resume traditional practices. In particular, Figure 3 provides aerial images of the $4000 \mathrm{~m}^{2}$ shaded (regenerative) farm and two $2000 \mathrm{~m}^{2}$ unshaded (sun-grown) coffee farms in the village for comparison between organic and conventional farming practices. The image of the shaded farm shows the drastic difference in biodiversity and 
species abundance between the two farming practices. We are currently in the process of analyzing these farms from an environmental science aspect as an extension of this study.
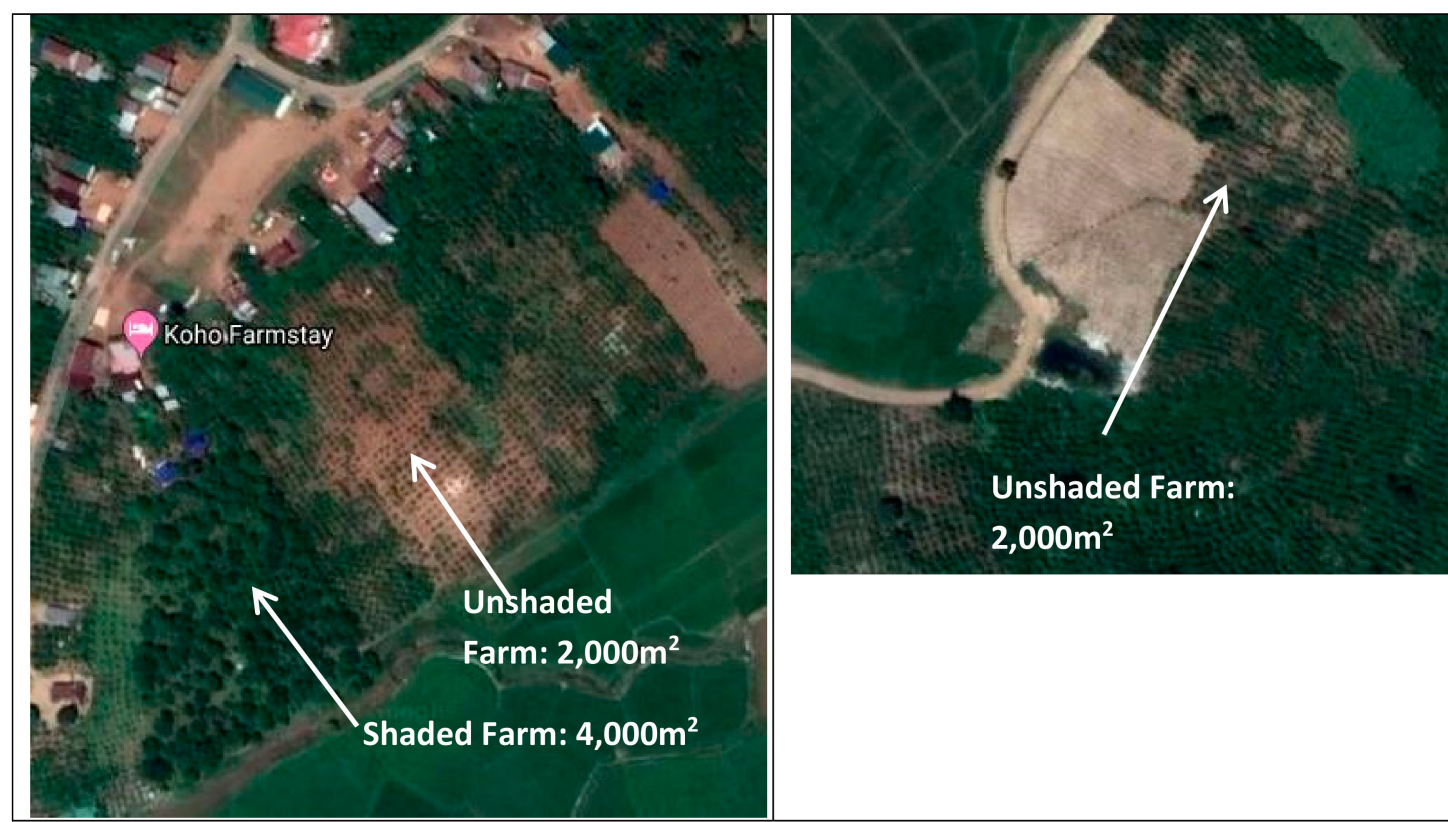

Figure 3. Aerial images of shaded (regenerative) and unshaded coffee farms. Source: Google Earth, Image @2019 DigitalGlobe.

Most of the sun-grown coffee trees in the $2000 \mathrm{~m}^{2}$ unshaded farms are over 25 years old, so yields are low. The farmers still use chemical fertilizers and pesticides to maintain productivity. The experimental model using shade-grown and regenerative farming practices has been implemented in 2014 on a few plots along the hillsides. One of the regenerative farms we visited is about $4000 \mathrm{~m}^{2}$. The farmer is a college graduate with a degree in soil management. In 2014, he planted 200 senna siamea trees next to 450 coffee trees to provide shade (Figure 3). In addition, the local government provided 70 macadamia trees to grow in 2017-2018 as an experiment to see if this type of tree could be a source of supplemental income to farmers in this community. The government also subsidized other crops such as durian and jackfruit to test their ability to grow in this particular climate, while also providing additional income to farmers traditionally dependent on coffee. On the farm, there are three cows, a dozen goats, and a few chickens. Previously, he had black pigs, but he had recently sold them in the local market before we arrived at his farm. The farmer mixes the animal manure with rice husks, straws, and yeast to make organic fertilizer. He does not use any chemical pesticides on his farm.

We asked the farmers to provide us with an estimated total costs, yields, total revenue, and net income per hectare of conventional (sun-grown) versus organic coffee production (shade-grown/regenerative) in harvest season 2018-2019. Table 2 shows the estimated figures.

Table 2. Conventional versus organic coffee production.

\begin{tabular}{ccc}
\hline & Conventional & Organic \\
\hline Yields per hectare & 2.5 tons & 1.5 tons \\
Total costs/ton & 12 mil VND $(\$ 522)$ & 26.67 mil VND (\$1159) \\
Total revenue/ton & 32 mil VND $(\$ 1391)$ & 93.33 mil VND (\$4058) \\
Net income/ton & 20 mil VND $(\$ 870)$ & 66.67 mil VND (\$2899) \\
\hline
\end{tabular}

Notes: The figures on the organic farms were based on estimates of the combined production from three farmers. Total costs include: management practices (i.e., fertilization, pest-control, shade management, soil conservation); costs of labor for the harvest and processing (including picking, wastewater management, wet processing, and drying); additional costs including fuel (for machinery), transport costs, interest on loans, and taxes paid. Exchange rate: $\$ 1=$ VND 23,000. 
Despite much higher estimated net income, many farmers in the village are still reluctant to switch to organic and regenerative farming practices. Since pests, such as the borer beetle and Roya fungus, are a pressing issue in the area, many farmers said they felt they had to continue using chemical pesticides and fertilizers to ensure their crops lived. This is especially important given the recent decline in coffee production throughout the farm region. Farmers noted that their aging trees are less productive, the soils are much drier and contain far fewer nutrients to support the health of the trees, and increases in heat waves and intense rainfall episodes have all been negatively impacting their coffee farms. It is feared that their production is already being impacted by many natural factors and that removing pesticides and fertilizers will make the situation worse. Several farmers commented that they have occasionally used the white halo fungus as a natural fungicide, but it has not always worked. Additionally, farmers perceive the labor and financial costs of changing their farming practices to be too great for them to afford. This was especially voiced by the older farmers, aged 55 and older.

\section{Data Analysis}

In this case study, our statistical approach to analyze the data is similar to a previous study of a farm community in the central highlands of Ethiopia, which employed samples t-test and principal component analysis [19]. We used a t-test to measure the significance of the difference between the mean scores of the male and female responses to the sustainable coffee indicators. Table 3 shows the results. Overall, male and female coffee farmers have relatively low mean scores across the three measures of sustainability and the t-test reveals that there is no statistically significant difference between the mean scores, with the exception of the "indicator inappropriate use of agrochemicals". This reveals a high degree of gender equality in the $\mathrm{K}^{\prime} \mathrm{Ho}$ community. This is expected given the fact that matriarchal traditions have governed ethnic minority communities in central highlands of Vietnam for over a millennium and is deeply rooted in the K'Ho culture, creating a balance in gender roles in their villages, especially given that the surrounding Vietnamese culture is male dominated. The evidence of the continued matriarchal society in the region is the traditional K'Ho marriage rights, including land rights. Today, a young K'Ho woman continues to decide on her marriage: she chooses her man, marries him, and brings him back to her home. Her home is on her land, since land is passed down through the generations of $K^{\prime} H o$ females. The villagers informed us these are two of the $\mathrm{K}^{\prime} \mathrm{Ho}$ traditions that have so far endured changes that have been occurring in their villages. These withstanding matriarchal traditions ensure a more gender balance in the $\mathrm{K}^{\prime} \mathrm{Ho}$ community.

The K'Ho farmers reported higher mean scores for social sustainability (female: 3.602; male: 3.585) followed by economic sustainability (female: 2.779; male: 2.866) and environmental sustainability (female: 2.181; male: 2.308). The farmers revealed that the social conditions in the village remain generally the same or better, the economic conditions are the same or worse, and the environmental conditions are getting worse compared to five years ago. The findings are consistent and supported by the socio-economic and environmental situations of the $\mathrm{K}^{\prime} \mathrm{Ho}$ described in previous section. Since the K'Ho Nộp migrated together and settled in Lăng Cú village years ago, they maintain a strong cohesive social bond under the administrative organizational structure, bòn, headed by an eighty-five-year-old village patriarch, kwang bòn. Customary laws guide family and community action and support the social organization and distribution of power within the community. Economically, the K'Ho Nộp indicated that their household status remains the same or worse than before, despite government efforts to improve their livelihoods. They attributed their lower economic condition mainly to coffee price volatility, rising living costs, and lack of market and product information. Environmentally, they attributed the worsening of the land mainly to climate change, deforestation, coffee pests and diseases, and degradation of water quality and supply. 
Table 3. T-test for sustainable coffee indicators.

\begin{tabular}{|c|c|c|c|c|c|}
\hline \multirow[b]{2}{*}{ Sustainable Coffee Indicators } & \multicolumn{2}{|c|}{ Female $(\mathrm{N}=17)$} & \multicolumn{2}{|c|}{ Male $(N=13)$} & \multirow[b]{2}{*}{$p$-Value } \\
\hline & Mean & $\begin{array}{c}\text { Std. } \\
\text { Deviation }\end{array}$ & Mean & $\begin{array}{c}\text { Std. } \\
\text { Deviation }\end{array}$ & \\
\hline Food insecurity and malnutrition & 2.706 & 0.686 & 2.538 & 0.628 & 0.498 \\
\hline Poor access to education and healthcare & 3.471 & 0.514 & 3.538 & 0.660 & 0.754 \\
\hline Gender inequality & 4.063 & 0.574 & 4.231 & 0.725 & 0.491 \\
\hline Green bean price volatility & 2.235 & 0.437 & 2.385 & 0.768 & 0.506 \\
\hline Long term decreasing real coffee prices & 3.125 & 0.500 & 3.000 & 0.816 & 0.616 \\
\hline Lack of market and product information & 2.688 & 0.704 & 2.769 & 0.725 & 0.761 \\
\hline Rising living costs and no living income & 2.250 & 0.577 & 2.423 & 0.813 & 0.509 \\
\hline Loss of biodiversity & 2.625 & 0.500 & 2.462 & 0.660 & 0.454 \\
\hline Soil erosion and degradation & 2.625 & 0.500 & 2.692 & 0.480 & 0.717 \\
\hline Inappropriate use of agrochemicals & 2.875 & 0.500 & 3.308 & 0.480 & $0.026 *$ \\
\hline Degradation of water quality and supply & 1.938 & 0.680 & 2.077 & 0.862 & 0.630 \\
\hline Evolving coffee pests and diseases & 1.875 & 0.619 & 2.077 & 0.494 & 0.348 \\
\hline Climate change and volatility & 1.563 & 0.629 & 1.385 & 0.650 & 0.462 \\
\hline
\end{tabular}

Notes: * significant at 0.05. Scale: (1) Much worse; (2) Worse; (3) Same; (4) Better; (5) Much better. Adapted from [2].

A principal component analysis (PCA) was performed to reduce the 18 indicators of sustainability into a smaller set of components. We used PCA with Varimax rotation to produce five farmer factors with eigenvalues higher than one [20,21]. The Kaiser-Meyer-Olkin (KMO) measure verified the goodness-of-fit of the variables for the analysis with a KMO equal to 0.47. Bartlett's test for sphericity: approximate Chi-square $=266.27, \mathrm{df}=153$, and $p$-value $=0.000$, indicated that the relations between variables were sufficiently large for PCA. These factors explained about $72 \%$ of the variance in farmers' sustainable coffee indicators. Cronbach's coefficient alpha was used to check for scale reliability. The alpha value above 0.5 is considered good reliability. Table 4 shows the results of PCA.

Table 4. Rotated component matrix.

\begin{tabular}{|c|c|c|c|c|c|}
\hline \multirow{2}{*}{ Sustainable Coffee Indicators } & \multicolumn{5}{|c|}{ Farmer Factors } \\
\hline & Factor 1 & Factor 2 & Factor 3 & Factor 4 & Factor 5 \\
\hline Rising living costs and no living income & 0.784 & & & & \\
\hline Poor access to education and healthcare & 0.708 & & & & \\
\hline Degradation of water quality and supply & 0.686 & & & & \\
\hline Food insecurity and malnutrition & 0.647 & & & & \\
\hline Inappropriate use of agrochemicals & 0.590 & & & & \\
\hline Long term decreasing real coffee prices & 0.586 & & & & \\
\hline Evolving coffee pests and diseases & 0.585 & & & & \\
\hline Green bean price volatility & & 0.858 & & & \\
\hline Land tenure uncertainty & & 0.763 & & & \\
\hline Ageing coffee trees & & 0.670 & & & \\
\hline Deforestation & & 0.535 & & & \\
\hline Climate change and volatility & & & 0.831 & & \\
\hline Lack of market and product information & & & 0.816 & & \\
\hline Migration and young people leaving coffee farming & & & & 0.863 & \\
\hline Loss of biodiversity & & & & 0.625 & \\
\hline Ageing farmer communities & & & & & 0.639 \\
\hline Soil erosion and degradation & & & & & 0.598 \\
\hline Gender inequality & & & & & 0.564 \\
\hline Explained variance (\%) & 28.84 & 14.05 & 13.14 & 8.38 & 7.42 \\
\hline
\end{tabular}




\section{- $\quad$ PCA: Factor One}

The first factor comprises three environmental sustainability indicators, two economic sustainability indicators, and two social sustainability indicators. This factor is related to a farmer's perceptions of long-term issues relating to coffee production within the K'Ho Nộp community in Lăng Cú village. The PCA indicates that this factor explains most of the variance in farmers' perceptions of sustainable coffee, which at $29 \%$ is higher than the other factors. Factor 1 has a reliability of 0.67 . The environmental sustainability indicators are degradation of water quality and supply, inappropriate use of agrochemicals, and evolving coffee pests and diseases. The farmers we interviewed stated that water is a main issue facing the community. The community uses water for agriculture from the Kala hydroelectric dam that flows into the creeks surrounding the community. The local government dug two wells to provide drinking water for the village when they initially settled the area. Over time, the wells could not provide enough water for the growing village, thus many families had to dig their own well. The cost for each well (excluding the electric pump and generator) was around 15 million VND (equivalent to \$650) to build, which required a loan from the bank to fund construction. At the flatland level, a shallow well is sufficient to provide clean water, but at a higher elevation on the hills they have to dig more expensive, deeper wells to reach water without aluminum contamination.

The farmers started using chemicals on their rice farms because the government provided them. For the coffee farms, farmers began applying chemicals after seeing other local farmers use them. The farmers claimed that they used chemical fertilizer because the soil is not fertile, but they have also attributed the lower soil quality to a history of chemical use. The quality of the land is worsening. The farmers we spoke with noted that over the years, coffee production in the region has drastically decreased. The farmers initially bought their spray pesticides from the local stores because they saw other farmers using them. They use chemical pesticides to treat borer (Hypothenemus hampei) and Roya fungus (Hemileia vastatrix), the two most common pests affecting coffee production worldwide. They also purchased pesticides from workshops hosted by organic pesticide companies that educate farmers on the negative effects of chemical pesticide use and benefits of organic pesticides. The farmers have occasionally used the white halo fungus (Cephalosporium lecanii) as a natural fungicide to fight off pests and diseases, which they noted sometimes works and sometimes does not. If the coffee trees grow well, they refrain from pesticide use.

The economic sustainability indicators are long term decreasing real coffee prices, rising living costs, and no living income. A long-term decrease in real coffee prices is a significant challenge for this small farm community. The K'Ho farmers in the village said they have a long-standing partnership with their green coffee buyers, who are also their chemical fertilizer suppliers. Those who cannot afford to purchase the fertilizers pay in green coffee beans at the end of the harvest season and receive payment in the amount of the difference between their green bean price and the amount of fertilizers they borrowed. They often get pressured from their buyers to lower the green bean prices and currently sell at 32,000 VND/kg (equivalent to \$1.39). In the past, in order to make up for the low prices, many of the green bean bags would have an added layer of dirt on the top and bottom of each bag to increase weight to earn more income. This was especially prevalent when the green bean price dropped during the coffee crisis and the farmers felt they had no choice in order to make ends meet. Rising living costs and no living income also challenged this farm community. In some harvest seasons when the coffee prices dropped significantly, farmers did not earn enough living income and had to take out loans from their coffee buyers/fertilizer suppliers. Many farmers also had to take out loans from their coffee buyers to pay for wedding and funeral expenses.

The social sustainability indicators are food insecurity and malnutrition and poor access to education and healthcare. Food insecurity and malnutrition are pervasive in this farm community. During the rainy season, the farmers are able to grow about $30 \%$ of the food they consume on their farms. During the dry season they have to purchase almost all their food, including vegetables, from local markets. Almost every household has chickens that provide eggs and meats throughout the year. They also have other animals on their farms such as cows, goats, and pigs, but these are all mainly 
kept for their manure fertilizer. Some livestock are used for religious sacrifice rather than for daily consumption. For example, pig and goat meat is prepared at occasional minor festivals, replacing the traditional, more expensive offering of buffalo meat. For major festivals such as the harvest ceremony, the whole community prepares a buffalo in addition to other traditional foods for prayers and offerings. These traditional festivities have become a financial burden to some families. Similar to other K'Ho subgroups, the K'Ho Nộp community in Lăng Cú village still respects their traditions, but some traditional laws have gradually disappeared in their community and festivities are getting smaller.

In terms of access to education and healthcare, the majority of the $\mathrm{K}^{\prime} \mathrm{Ho}$ farmers are illiterate. Only about 3 or 4 individuals from the 100 families in the village are able to read and write in the K'Ho language. Most communication is thus by word of mouth, and many farmers agreed that they did not see a big need for written $K^{\prime} H o$ language. When it comes to tracking information for their farms, many farmers can read and write some information in Vietnamese. Some children in the village are able to attend college. In order to pay tuition fees, families have to borrow money from the bank or other sources. Several families borrow from the local fertilizer suppliers in order to send their children to school.

Most traditional medical practices have been lost. Some minor illnesses are still treated with traditional knowledge such as eating guava leaves to decrease stomach aches, but the majority of illnesses are treated with modern medicine at the new community medical clinic in the village. In addition to general weakness complained by the farmers such as back pain and broken bones, they attributed their agrochemical health related problems to their work in the field: hypertension, respiratory tract, eye irritation and discomfort, that seems to hit the majority of the farmers around the age of 50 after many years of being exposed through skin contact and inhalation. Specifically, farmers who apply chemicals in their field attributed their growing physical weakness and increase in illnesses to the use of those chemicals. They noted that community members who had been sick the most frequently were the ones who had been working closely with chemicals on the coffee farms, which may increase the risks of developing various kinds of human cancers. After recognizing the increases in illnesses, the farmers decided to limit the amount of chemicals they use on the farms.

\section{- $\quad$ PCA: Factor Two}

The second factor comprises three economic sustainability indicators and one environmental sustainability indicator. These indicators are related to the economic challenges of price volatility, aging coffee trees, and land tenure security, as well as issues with deforestation in this region. This factor explains $14 \%$ of the variance in farmers' perceptions of sustainable coffee. Factor 2 has a reliability of 0.72. The farmers said they enjoyed growing coffee until recently, when both production and green bean prices have been low. Robusta coffee in Di Linh district is taking "too much work to grow for little pay", noted one farmer. Commercialized Robusta beans in Di Linh district are low in quality, selling at about 20,000-35,000 VND/kg. The coffee buyers are Vietnamese in Di Linh town center, and they come directly to the village to buy coffee beans and collect money from selling fertilizers and pesticides. One farmer commented that only the Vietnamese would go door to door collecting money; the $\mathrm{K}^{\prime} \mathrm{Ho}$ in the village would not because everyone knows one another. In terms of aging coffee trees, the farmers said that despite the government support of replanting and replacing old coffee trees, their village has not benefitted from the program. Only a few, very poor households were supported by the local government. Most of the coffee trees are over 25 years old, which the farmers received from the government when they first resettled in the village. The farmers said that even with the initial 100 coffee trees and a couple of bags of fertilizer given to them, they have only recently finished paying off their debt. The older farmers stated that they do not want to replant or to switch to shade-grown coffee because they do not want to incur more debt or to take on new work. Many of the younger farmers are waiting to see the results from the regenerative farms in the village before making their decision.

Deforestation is another issue under factor 2. The destruction of the forests was caused by agricultural expansion in this region in the 1990s when the price of coffee soared and migrants began 
flooding into this region to grow coffee. One of the farmers in his mid-forties noticed that the Gung Ré commune is the site for frequent logging because of its geographic location surrounded by mountains. He has witnessed loggers (whether legal or illegal) cutting and transporting timbers from the forest protection areas in the mountains passing through the village. He also stated that the local people also collect wood in nearby forests for a number of reasons, including for use as fuel owing to rising coal prices.

\section{- PCA: Factor Four}

The fourth factor comprises one social sustainability indicator-migration and young people leaving coffee farming, and one environmental sustainability indicator-loss of biodiversity. This factor explains $8 \%$ of the variance in farmers' perceptions of sustainable coffee. Factor 4 has a reliability of 0.52 . The older farmers reported that they do not see any issue with young people in the village leaving coffee farming. In fact, most children who leave the village to attend university return to the farm and rural life. Generally, K'Ho young adults simply do not enjoy living the city lifestyle. In addition, even with a college degree, they find it difficult to get a job in the city because they lack business connections. In Vietnam, networks and connections are highly valued; therefore, a lack of connection in the cities limits the mobility of the minority groups. We met one woman in her twenties who studied banking in college but could not find a banking job because she did not have the right connections, so she returned to the village. On the other hand, a farmer with a college degree in soil management volunteered to return back to the village despite having a good job in the city because he thought his skills would be more valuable to his community.

The loss of biodiversity because of many years of chemical fertilizer and pesticide use has threatened this farm community. The regenerative farming practices, along with the incorporation of shade trees, not only helps restore the soils, but also promotes higher biodiversity as shade trees provide habitat for diverse species.

- PCA: Factors Three and Five

The third factor comprises one environmental sustainability indicator and one economic sustainability indicator, including climate change and volatility, and lack of market and product information, respectively. This factor explains $13 \%$ of the variance in farmers' perceptions of sustainable coffee. Cronbach's alpha based on standardized items indicated that factor 3 is unreliable. The fifth factor comprises two social sustainability indicators-aging farmer communities and gender inequality, and one environmental sustainability indicator-soil erosion and degradation. This factor explains 7\% of the variance in farmers' perceptions of sustainable coffee. Cronbach's alpha based on standardized items also indicates that factor 5 is unreliable.

\section{Conclusions}

This case study revealed the current perceptions of sustainable coffee production by the $\mathrm{K}^{\prime} \mathrm{Ho}$ Nộp ethnic minority in Gung Ré commune of Di Linh district. The principal component analysis (PCA) of the study's tri-part sustainability survey-environmental, economic, and social-sustainability, produced five factors of which factors one, two, and four were reliable.

Factor one was based on the long-term issues farmers perceived with coffee production, including seven indicators, two economic, two social, and three environmental, such as rising living costs, decreased coffee prices, evolving pests and diseases, degradation of water supplies, and food insecurity. Farmers expressed their concern that the economic volatility and changing climate in the region were forcing them to produce in mass quantities. Farmers perceived this trend as a barrier to shifting toward sustainable production methods.

Factor two included four indicators, three economic and one environmental, that were based on the perceptions of economic uncertainty of production levels and land stability for future production. Farmers expressed their concern that the past thirty years of high pesticide and fertilizer use had caused 
irreversible damage to the land, forcing them to continue adding fertilizers to ensure their aging trees are able to continue producing cherries. Factor four emphasized the challenges that young people in the village currently experienced and their aspirations to find a sustainable solution to improve coffee value and quality, while preserving the ecological balance and biodiversity of their farm community for future generations.

Although women own the land and represent the farms in this matriarchal community, both men and women revealed similar perceptions of their current state of economic, environmental, and social sustainability, as well as noting similar perceived barriers limiting their transition to sustainable production methods. The only indicator significantly different between the male and female farmers was in regard to the inappropriate use of agrochemicals, which was perceived as being worse by women.

To summarize, this case study revealed that the economic instability of coffee farming in the Gung Ré commune of Di Linh district is limiting farmers' ability to initiate a transition to sustainable coffee production. Fears of the changing climate conditions, increasing pest prevalence, volatility of coffee prices, and decreased farm productivity are all factors contributing to continued farmer use of pesticides and fertilizers. A few young farmers that returned to the village after attending agricultural college are investing in their farm transition to sustainable production methods. We anticipate their production in the next few years to yield higher economic stability and prosperity than their conventional farming neighbors and to act as a model for others to begin the transition. Increased economic support in this region through established coffee partnerships, subsidized farm equipment for improvement, or other means of promoting economic stability will allow farmers to successfully transition to more sustainable farming practices.

For further investigation as a larger part of this project, we are currently conducting a case study on regenerative farming practices in this village. Our initial analysis of soil samples taken from an experimental farm using regenerative practices and two conventional farms indicated that the soil of the regenerative farm, enriched with organic manure, is comparable to, or even superior to the soil samples on the conventional farms, enhanced by chemical fertilizers. In terms of biodiversity, the regenerative farm has a greater abundance of invertebrates and other species than both conventional farms. Economically, the regenerative farm generated higher net returns in the 2018-2019 harvest, despite producing less coffee. These are very encouraging findings that we plan to share with other farmers in the community.

Author Contributions: Conceptualization, Q.V.L., G.J.; methodology: Q.V.L., G.J., S.C.; investigation: Q.V.L., G.J., S.C., D.-T.L.; data curation: Q.V.L., G.J., S.C., D.-T.L.; formal analysis: Q.L.V.; visualization: D.-T.L., Q.L.V.; writing—original draft preparation: Q.V.L; writing—review and editing: Q.V.L., G.J., S.C.; supervision: Q.V.L. All authors have read and agreed to the published version of the manuscript.

Acknowledgments: The authors are very grateful for the valuable comments and suggestions of three anonymous reviewers which helped to improve this paper considerably. We are also very grateful for the constructive contributions of the coffee farmers, K'Ho community leaders, and local authorities in Lăng Cú village. Responsibility for any errors in this case study remains our own.

Conflicts of Interest: The authors declare no conflict of interest.

\section{References}

1. Bunn, C.; Laderach, P.; Rivera, O.; Kirschke, D. A bitter cup: Climate change profile of global production of Arabica and Robusta coffee. Clim. Chang. 2015, 129, 89-101. [CrossRef]

2. Panhuysen, S.; Pierrot, J. Coffee Barometer 2014; IUCN Nederlands: Amsterdam, The Netherlands; Hivos: The Hague, The Netherlands; Oxfam Novib: The Hague, The Netherlands; Solidaridad: Utrecht, The Netherlands; WWF: Zeist, The Netherlands, 2014.

3. Babbar, L.I.; Zak, D.R. Nitrogen loss from coffee agroecosystems in Costa Rica: Leaching and denitrification in the presence and absence of shade trees. J. Environ. Qual. 1995, 24, 227-233. [CrossRef]

4. Haggar, J.; Schepp, K. Coffee and Climate Change Impacts and Options for Adaption in Brazil, Guatemala, Tanzania and Vietnam. In Climate Change, Agriculture and Natural Resources; University of Greenwich: London, UK, 2014. 
5. World Coffee Research. Creating the Future of Coffee. Annual Report 2017. Available online: https://worldcoffeeresearch.org (accessed on 10 April 2019).

6. Li, L.; Sun, J.; Zhang, F.; Guo, T.; Bao, X.; Smith, F.A.; Smith, S.E. Root distribution and interactions between intercropped species. Oecologia 2006, 147, 280-290. [CrossRef] [PubMed]

7. Avelino, J.; Zelaya, H.; Merlo, A.; Pineda, A.; Ordoñez, M.; Savary, S. The intensity of a coffee rust epidemic is dependent on production situations. Ecol. Model. 2006, 197, 431-447. [CrossRef]

8. McCook, S.; Vandermeer, J. The big rust and the red queen: Long-term perspectives on coffee rust research. Phytopathology 2015, 105, 1164-1173. [CrossRef] [PubMed]

9. Ministry of Agriculture and Rural Development of Vietnam (MARD). Lâm Đồng: Model of Supply Chain in Sustainable Coffee Production. 2017. Available online: https://www.mard.gov.vn/Pages/lam-dong-mo-hinhchuoi-lien-ket-trong-san-xuat-ca-phe-che-ben-vung.aspx (accessed on 10 April 2019).

10. K'Ho Ethnic Minority (in Vietnamese). Văn Hóa Du Lịch [Tourism Culture]. 2013. Available online: http://songchodamme.blogspot.com/2013/07/dan-toc-co-ho.html (accessed on 10 April 2019).

11. Nguyen, T.H. Phát họa chân dung dân tộc Kơ Ho [Portrait of the K’Ho ethnic minority]; Phuong Dong Publishing House: Ho Chi Minh City, Vietnam, 2017. (in Vietnamese)

12. Lâm Đồng Government. Di Linh District. (in Vietnamese). Available online: http://www.lamdong.gov. vn/VI-VN/CHINHQUYEN/BO-MAY-TO-CHUC/HUYEN-TP-TX/Pages/huyen-dilinh.aspx (accessed on 10 April 2019).

13. Nguyen, N.H. Policy for Environmentally Sustainable Development: Perspectives from Vietnam. In Environmental Policies in Asia: Perspectives from Seven Asian Countries; World Scientific Publishing: Singapore, 2012.

14. United States Department of Agriculture (USDA). Vietnam: Coffee Annual, Attaché Reports (GAIN). Available online: https://www.fas.usda.gov/data/vietnam-coffee-annual-3 (accessed on 10 April 2019).

15. Lâm Đồng Portal (in Vietnamese). Available online: http://www.lamdong.gov.vn/VI-VN/HOME/Pages/ default.aspx (accessed on 10 April 2019).

16. Lâm Đồng Online (in Vietnamese). Available online: http://baolamdong.vn/xahoi/201703/ngay-moi-o-langku-2788291 (accessed on 10 April 2019).

17. Le, Q.V.; Wild, B.; Jackels, S. The case of Café Ambiental, SPC: A new business model for a Nicaraguan fair trade cooperative. World Dev. Perspect. 2017, 6, 35-37. [CrossRef]

18. Le, Q.V.; Jovanovic, G. From Crisis to Specialty Coffee: The case of Nicaraguan smallholder cooperatives and Jesuit business education for sustainability and justice. J. Manag. Glob. Sustain. 2019, 7, 105-130.

19. Abi, M.; Kessler, A.; Oosterveer, P.; Tolossa, D. How farmers' characteristics influence spontaneous spreading of stone bunds in the highlands of Ethiopia: A case study in the Girar Jarso woreda. Environ. Dev. Sustain. 2018, 1-19. [CrossRef]

20. Nardo, M.; Saisana, M.; Saltelli, A.; Tarantola, S.; Hoffmann, A.; Giovannini, V. Handbook on Constructing Composite Indicators: Methodology and User Guide; OECD Statistics Working Papers: Paris, France, 2005.

21. Abdi, H.; Williams, L.J. Principal component analysis: Overview. Wiley Interdiscip. Rev. Comput. Stat. 2010, 2, 433-459. [CrossRef]

(C) 2020 by the authors. Licensee MDPI, Basel, Switzerland. This article is an open access article distributed under the terms and conditions of the Creative Commons Attribution (CC BY) license (http://creativecommons.org/licenses/by/4.0/). 